\title{
A New Species of Gomphonema (Bacillariophyta) from Mammoth Cave, Kentucky
}

\author{
By Sam L. VanLandingham ${ }^{1}$ ) \\ With 1 figure in the text
}

In a previous paper appearing in this Journal (VanLandingham, 1965a), a series of diatoms was described from Mammoth Cave, Kentucky, from material collected in the cave by Dr. George Claus, Department of Marine Science, Long Island University, Greenvale, New York. Descriptions of three species of Cymbella from this material were not to be found in the literature and were described as new species in a paper in this Journal (1965b). In addition to the three species of Cymbella, a new species of Gomphonema is now proposed.

$$
\text { GOMPHONEMA HOTCHKISSII sp. nov. }
$$

Dimensions: Length $16 \mu$, width $5.5 \mu$, striae 9-10 in $10 \mu$.

Holotypus (nomenclatural type): VanLandingham Collection, slide 13 a.

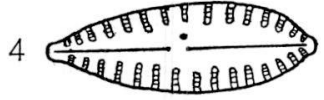

I c onotypus (nomenclatural type): Original camera lucida drawing by Dr. George Claus, Department of Marine Science, Long Island University, Greenvale, New York, Fig. 2; see also VanLandingham, 1965 a, Fig. 4.

Type locality: Mud from small ponds in Mammoth Cave (National Park), Kentucky.

Latin description: Valvae elongatae, lanceolatae; apicibus valvae rostratis distincte; area axiali gibbera valide; striis levite radiantibus; striae transapicales $\mathbf{9 - 1 0}$ in spatio 10 micronis. Longitudo cellularum, 16 micra, latitudo earum, 5.5 micra.

\section{Discussion}

This diatom is named in honor of Dr. A. T. Hotchkiss, Department of Biology, University of Louisville, Louisville, Kentucky.

1) Department of Biology, University of Louisville, Louisville, Kentucky. 
The most conspicuous features of this diatom are the subcapitate apices and the broad elliptical-shaped axial area. Apparently, it does not closely resemble any known diatom, but does show a superficial resemblance to Gomphonema parsulum Kützing which possesses a much less narrow axial area.

\section{SUMMARY}

In some materials collected from Mammoth Cave, Kentucky, a diatom was found which could not be identified with any known species. A taxonomic description of Gomphonema hotchkissii nov. spec. is given.

\section{ZUSAMMENFASSUNG}

In einigen in der Mammoth-Höhle, Kentucky, gesammelten Proben fand sich eine Kieselalge, die zu keiner bekannten Form gehört. Eine taxonomische Beschreibung der neuen Art Gomphonema hotchkissii nov. spec. ist angeführt.

\section{REFERENCES}

VanLandingham, S. L. (1965a) - Diatoms from Mammoth Cave, Kentucky. Internat. J. Speleol. 1 (4) : 517-539.

- $(1965 \mathrm{~b})$ - Three new species of Cymbella from Mammoth Cave, Kentucky. Internat. J. Speleol. 2 (1-2): 131-136. 